\title{
El ve el bileğinin travmatik çıkıkları
}

\section{Traumatic dislocations of hand and wrist}

\author{
Kemal Özaksar ${ }^{1}$, Sertan Hancıoğlu² \\ 'EMOT, El Mikrocerrahi Ortopedi ve Travmatoloji Hastanesi \\ ${ }^{2}$ SBÜ Tepecik Eğitim ve Araştırma Hastanesi Ortopedi ve Travmatoloji Kliniği, İzmir
}

\begin{abstract}
Günlük aktivitelerimizi yapmamızı sağlayan el ve el bileği, bu fonksiyonlarını yerine getirebilmek amacıyla birçok kemikten ve farklı özellikleri olan eklemlerden meydana gelmiştir. Eklemler, lokalizasyonlarına göre interfalangeal, metakarpofalangeal, karpometakarpal, karpal ve radyokarpal eklemler olarak sınıflandırılabilir. El bölgesi çıkıkları çoğunlukla spor yaralanmaları ve basit düşme gibi travmalar sonucu oluşmaktayken, el bileği çıkıkları yüksek enerjili travmalar sonrası ortaya çıkar ve çoklu travmanın birer parçası olabilir. Bu tip yaralanmaları değerlendirmek için el ve el bileği anatomisine hakim olmak gerekir. Bu eklemlerin çıkıkları bir bütün olarak ele alınmalı ve yaralanması muhtemel bağlar, tendonlar, kırık parçalar dikkatlice değerlendirilmelidir. Tedavi mümkün olan en erken dönemde yapılmalı, redüksiyonun kapalı yöntemler ile sağlanamadığı durumlarda cerrahi tedavi uygulanmalı, fonksiyonların yeniden kazanılması amacıyla erken harekete izin veren yöntemler tercih edilmelidir. El ve el bileği eklem çıkıklarından sonra, tekrarlayan kapalı redüksiyon girişimleri, travmatik durumlarda yapılan açık redüksiyonlar ya da eklemin uzun süreli çıkık kalmasına bağlı olarak; dejeneratif artrit, osteonekroz ve sertlik gibi komplikasyonlar görülebilir.
\end{abstract}

Anahtar sözcükler: parmak; el bilek; eklem; çıkık
The skeleton of the human hand and wrist consists of many bones and joints with different characteristics, which gives us the ability to do daily activities. According to their localisations hand and wrist joints can be shortly classified as interphalangeal, metacarpophalangeal, carpometacarpal, carpal and radiocarpal joints. While hand joint dislocations most commonly occur from sport injuries and from simple fall, causes of wrist joint dislocations are mostly high-energy traumas. Therefore, wrist dislocations can be a part of multi-trauma. To evaluate these dislocations precisely, one needs to have a detailed understanding of hand and wrist anatomy. These dislocations should be evaluated as a whole; ligaments, tendons, susceptible to injury, and possible fractures should be taken in consideration. In order to gain early range of motion, appropriate treatment should be started as soon as possible. If reduction can not be achieved by closed techniques, surgical treatment should be chosen. Complications of hand and wrist joint dislocations include: degenerative arthritis, osteonecrosis, and stiffness that may arise from repeated attempts at closed reduction, open reduction of traumatic cases, or prolonged dislocation.

Key words: finger; wrist; joint; dislocation

\section{DISTAL INTERFALANGEAL EKLEM ÇIKIKLARI}

Distal interfalangeal eklem (DiP) bikondiler bir eklem olup her iki tarafinda ana ve yandaş kollateral bağlar ile volarde volar plak ile eklemin stabilizasyonu sağlanır. Kollateral bağlar eklemin statik stabilitesini sağlarken, ekstansiyon ve fleksiyon yönlerindeki kuvveti dengeleyen terminal ekstansör tendon ile uzun fleksör tendonlar dinamik stabiliteyi sağlar. DiP çıkıkları genellikle eklem çevresi kırıkları ile ya da tendon kopmaları ile birlikte görülür. Kapalı izole DiP eklem çıkıkları oldukça nadirdir. En sık yaralanma mekanizması topla yapılan sporlarda topun parmak ucuna DiP eklem hiperekstansiyonda iken çarpması ile oluşan aksiyel yüklenme sonrasında volar plakanın yırtılması ve eklemin dorsale yer değiştirmesi ile olur (Şekil 1). ${ }^{11]}$ Çıkık genellikle dorsale olmakla birlikte volare (Şekil 2) ve laterale de olabilir. Ezici ve döndürücü kuvvetler ile daha çok volare çıkıklar görülür. ${ }^{[2]}$

DiP eklem çıkıklarının muayenesinde yandaş yumuşak doku yaralanmalarının, duyunun, kapiler dolumun, aktif-pasif hareketin, terminal ekstansör tendonun, fleksör dijitorum profundusun ve eşlik eden kırıkların değerlendirilmesi önemlidir. Direkt grafi ön-arka ve yan olarak çekilmeli, eşlik eden kırık varlığı ve diğer

- İletişim adresi: Doç. Dr. Kemal Özaksar, EMOT, El Mikrocerrahi Ortopedi ve Travmatoloji Hastanesi, 1418 Sokak No: 14 , Kahramanlar, İzmir, Türkiye Tel: 0532 - 5083402 e-posta: kemal.ozaksar@hotmail.com

- Geliș tarihi: 9 Kasım 2018 Kabul tarihi: 9 Kasım 2018 

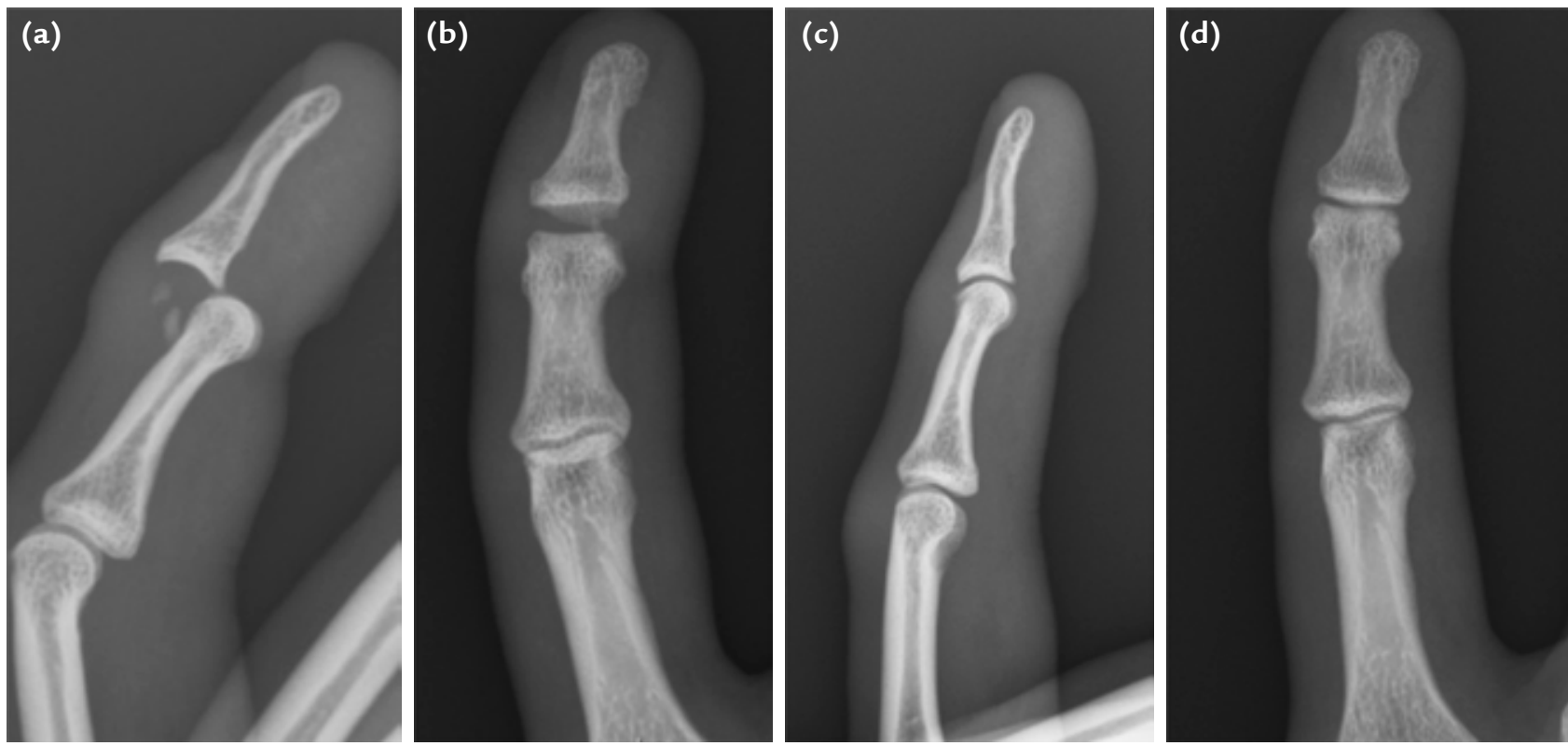

Şekil 1. a-d. Voleybol oyuncusunun eline topun dik çarpması sonrasında gelişen DiP eklem dorsal çıkı̆̆ı. Lateral grafide distal falanksın dorsale yer değiştirmesi (a). Ön-arka grafide eklem aralığının genişlemiş görünümü (b). Kapalı redüksiyon sonrası eklemin konsantrik redüksiyonu $(c, d)$.
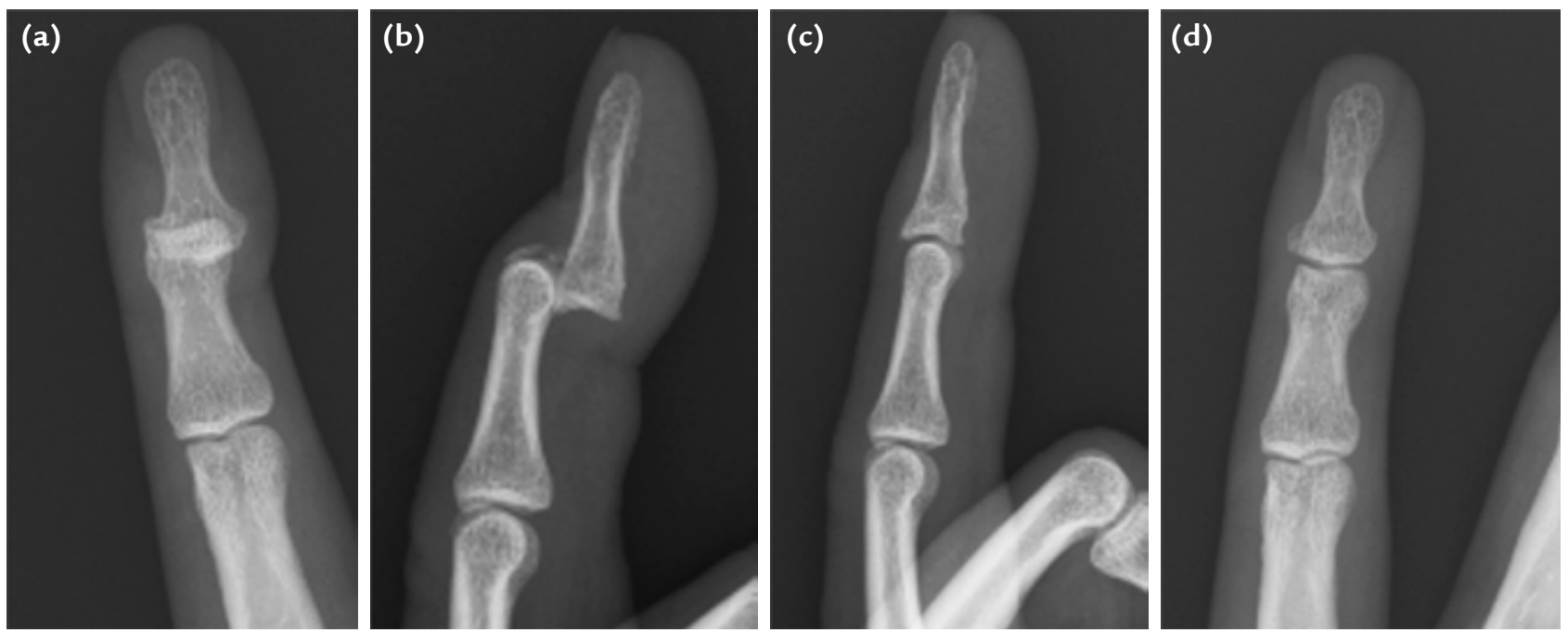

Şekil 2. a-d. Top çarpması sonucunda 5. parmak DiP eklem volar çıkığı. Ön arka ve yan grafilerde distal falanksın volare yer değiştirmesi $(\mathbf{a}, \mathbf{b})$. Kapalı redüksiyon sonrası eklemin konsantrik redüksiyonu (c, d).

eklemlerin durumu değerlendirilmelidir. Çıkıklar sıklıkla açık çıkıklardır; bunlar, genellikle fleksör katlantıda laserasyon şeklinde görülür ve kontamine eklem olarak tedavi edilmelidir. Tedavide ilk olarak kapalı yerleştirme yapılmalıdır. Parmak blok anestezisi ile uzunlamasına traksiyon yapılarak distal falanks ekstansiyonda çekilir, dorsal çıkıklarda distal falanks bazisine dorsalden, palmar çıkıklarda volarden bastırılarak redükte edilir. DiP eklem hafif fleksiyonda 2-3 hafta atelleme uygulanır. Üç haftanın üzerindeki yaralanmalarda, kapalı yerleştirme ile düzelmenin sağlanamadığı veya instabilite oluştuğu durumlarda cerrahi tedavi uygulanmalıdır. ${ }^{[3]}$ Bazı yazarlar kapalı redüksiyon sonrasında lateral stres uygulanarak kollateral bağların değerlendirilmesini önermektedirler. Volar çıkıklar dorsal çıkıklara göre daha instabil olma eğilimindedir. Eğer eklem stabil ise atelleme, değil ise $0,9 \mathrm{~mm}$ K-teli (Kirschner teli) ile dört hafta tespit iyi bir stabilite sağlar. Eklemin 

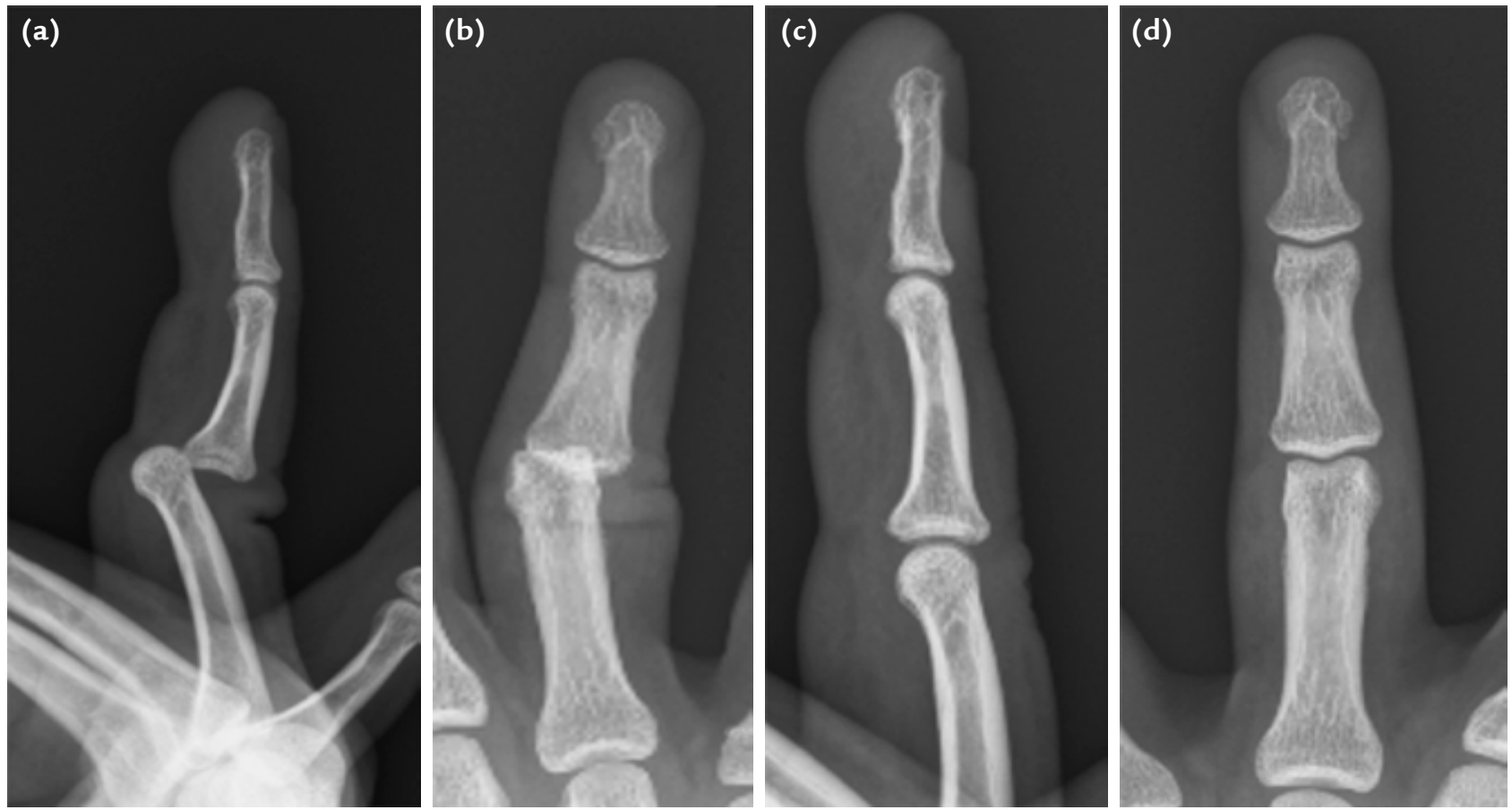

Şekil 3. a-d. Lateral grafide orta falanksın dorsale yer değiştirmesi (a). Ön-arka grafide eklem aralığının bozulmuş görünümü (b). Kapalı redüksiyon sonrası eklemin konsantrik redüksiyonu (c, d).

redükte olmamasının nedeni, volar plağın araya girmesi ya da fleksör dijitorum profundusun subluksasyonu olabilir; bu gibi durumlarda açık redüksiyon ve dört hafta K-teli tespiti yapılmalıdır. ${ }^{[4,5]}$

\section{PROKSIMAL INTERFALANGEAL EKLEM ÇIKIKLARI}

Proksimal interfalangeal eklem (PiP) orta falanks ile proksimal falanks arasında bulunan menteşe tipi bir eklemdir. Eklem fleksiyon ekstansiyon yönünde hareket etmekte olup stabilitesi kemiksel uyum ve çevre yumuşak dokular tarafindan sağlanır. Proksimal falanksın kondilleri orta falanksın konkav yüzeyleri ile eklemleşir. Orta falanksın konkav eklem yüzleri arasında bulunan çıkıntı proksimal falanksın kondilleri arasındaki çentiğe girerek kemik stabiliteyi sağlar. İki kemik arasındaki bu uyum fleksiyon hareketine izin verirken, rotasyonel ve lateral plandaki hareketi sınırlandırır. ${ }^{[6]}$ Eklemin her iki tarafinda bulunan kollateral bağlar radyal ve ulnar deviyasyonu sınırlarken, eklemin volar yüzünü kaplayan volar plak hiperekstansiyonu sınırlar. Kollateral bağlar ve volar plak, eklemi güçlü bir kutu şeklinde sararak stabilitesini sağlar. ${ }^{[7]}$

PiP çıkıkları tüm çıkıkların \%10'unu oluşturur. Çıkıklar genellikle hiperekstansiyonda diklemesine yüklenme ile oluşur ve sıklıkla toplu sporlarla uğraşan genç sporcularda daha çok 4. ve 5. parmaklarda görülür. ${ }^{[8]}$ Eklem çıktığı zaman ağrı, ödem ve deformite oluşur. Duyu, kapiler dolum, renk, Isı değerlendirilmesi sonrasında parmağın hareketine bakılır. PiP eklemin her planda palpasyonu ile oluşan hassasiyet bize hangi yapıların yaralandığı hakkında fikir verebilir, fakat bazı parmaklarda aşırı ödem ve ağrı nedeniyle bu muayene yapılamayabilir. Radyografide; ön-arka, yan ve oblik grafiler değerlendirilerek, çıkığın hangi yöne olduğu ve kırık eşlik edip etmediği anlaşılır. PiP eklem çıkıkları dorsal, volar ve lateral olmak üzere üçe ayrılır. Her bir çıkık tipinin kendine has yaralanma mekanizması ve eşlik eden yumuşak doku hasarı bulunmaktadır. En sık dorsal çıkıklar görülür. Dorsal çıkıklarda orta falanks dorsale yer değiştirirken, volar çıkıklarda palmara yer değiştirir.

\section{Dorsal PiP Çıkıkları}

Yaralanma mekanizması hiperekstansiyondaki parmağa diklemesine gelen yüklenme sonrasında orta falanksın proksimal falanks kondillerine çarpması sonrasında oluşur. Bu mekanizma, kollateral bağların proksimalden ve volar plağın distal yapışma yerinden kopmasına neden olur. Orta falanks dorsale yer değiştirirken, volar plak orta falanks yapışma yerinden avulse olur (Şekil 3). Çıkık oluşurken, volar plak avulsiyon kırıkları ya da orta falanks 

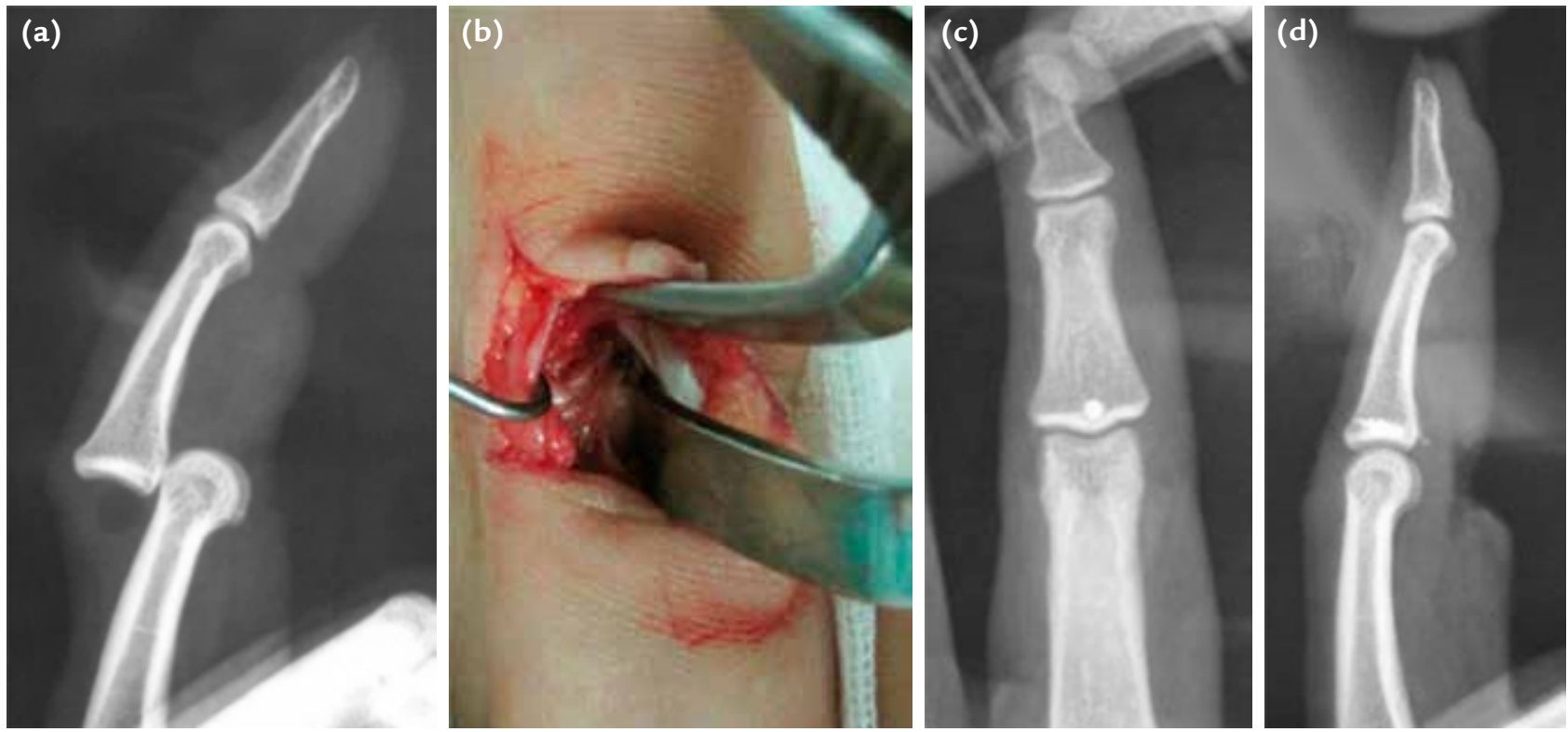

Şekil 4. a-d. Lateral grafide orta falanksın dorsale yer değiştirmesi (a). Volar plağın eklem arasındaki interpozisyonunun volar yaklaşım ile çıkarılması (b). Orta falanks proksimalinden kopan palmar plağın çapa dikiş ile orta falanksa tespiti (c). Tespit sonrası ön-arka ve lateral grafide eklemin konsantrik redüksiyonu (d).

volar dudağında makaslama kırığı oluşabilir. ${ }^{[9]}$ Eğer ilk günler içerisinde çıkık görülür ise, bunların çoğu parmak bloğu ve kapalı redüksiyon ile tedavi edilebilir. Kapalı redüksiyon, uzunlamasına çekme sonrasında eklemin dorsalden bastırılarak fleksiyona alınması ile sağlanabilir. Kapalı redüksiyon sonrasında uygun rehabilitasyon yöntemi, stabil olan çıkıklarda iki hafta yandaş parmağa tespit ederek, hiperekstansiyondan kaçınarak erken harekete başlanmasıdır. Fakat stabilite yeterli değil ise, stabil olduğu açıda ekstansiyonu bloklayan dorsal atelleme ya da 8 şeklindeki ateller kullanılabilir. Bu ateller aktif fleksiyona izin verir. Her hafta ekstansiyon dereceleri azaltılarak redüksiyon radyolojik olarak takip edilmelidir. Eğer uzun süre fleksiyon ateli ile takip yapılırsa, volar plak distal yapışma yerinin daha distalinde iyileşir; bu da fleksiyon kontraktürüne neden olabilir ve yalancı düğme iliği deformitesi oluşabilir. Küçük volar dudak kırıkları için bir şey yapmaya gerek yoktur; volar dudak kırığı instabilite oluşturuyorsa tespit etmek gerekebilir (Şekil 4). Eğer yaralanma mekanizmasında torsiyonel kuvvetler de işin içine girerse, nadir de olsa eklem interpozisyonu ile kapalı redüksiyon engellenebilir. ${ }^{[10]}$ Dorsal çıkıklarda eklem interpozisyonuna en sık neden olan yapı volar plaktır, FDS (flexor digitorum superficialis) ve FDP (flexor digitorum profundus) tendonları da redüksiyonu engelleyebilen diğer yapılardır. ${ }^{[11,12]}$ Eklemin kapalı redükte olmadığı durumlarda açık redükte edilip interpoze yapıların eklem aralığından çıkarılarak redüksiyonun sağlanması gereklidir (Şekil 5).

\section{Volar PiP Çıkıkları}

Volar çıkıklar dorsal ve lateral çıkıklardan daha az görülür. Direkt volar translasyon ile ekstansör mekanizmanın santral slibi dorsal dudaktan kopar veya avulse olur; buna kollateral bağlardan birinin de kopması eşlik eder. Kapalı redüksiyon, parmak bloğu ile metakarpofalangeal eklem fleksiyonda iken uzunlamasına çekme sonrasında ekstansiyona alınarak yapılır. ${ }^{[9,13]}$ Genellikle kolay redükte olur ve santral slibin iyileşmesi için 3-4 hafta ekstansiyonda tespit gereklidir. Redüksiyon sonrasında santral slip yırtık olsa da, lateral bantların sağlam kalmasına bağlı ekstansiyon yapılabilir; eğer ekstansiyonda yeterli immobilizasyon yapılmaz ise santral slip trianguler bağları gererek, lateral bantların volare sublukse olmasına neden olur. Sublukse lateral bantlar nedeniyle PiP eklem ekstansiyona gelemez, terminal ekstansör tendonda gerilme olur, DiP eklem hiperekstansiyona giderek düğme iliği deformitesi ile sonuçlanır (Şekil 6). Döndürücü kuvvetlerle oluşan çıkıklarda, kollateral bağlardan biri koparak diğeri sağlam kalır, santral slip kondillerden biri üzerinden kayar ve santral slip ile lateral bant arasında uzunlamasına bir yırtık oluşur; orta falanks sağlam kalan 

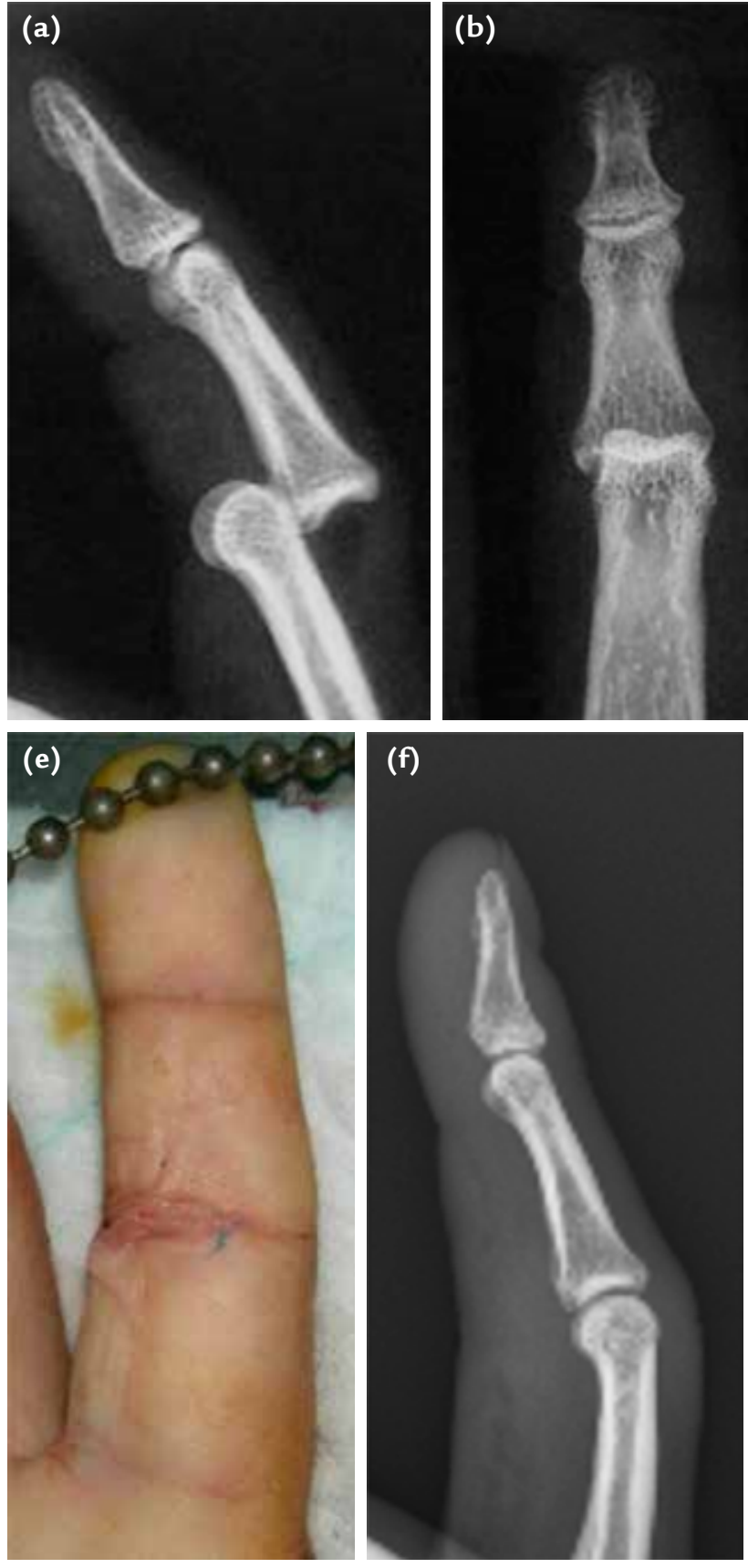
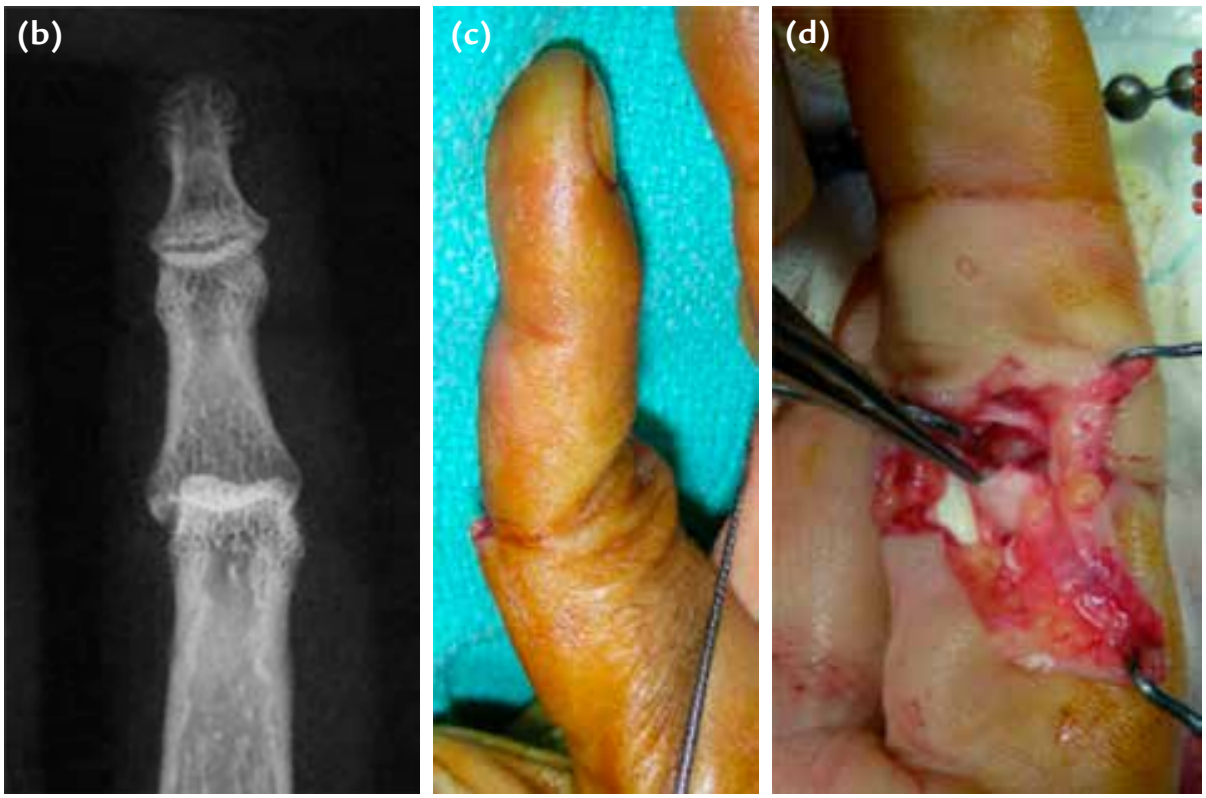

Şekil 5. a-f. Dorsale çıkık X-ray görüntüleri (a, b). Kapalı redükte olmayan PiP eklem dorsal çıkığı klinik görünümü (c). Redüksiyonu engelleyen volar plağın eklemden çıkarılması (d). Eklemin redükte halinin klinik ve radyolojik görünümü $(e, f)$.
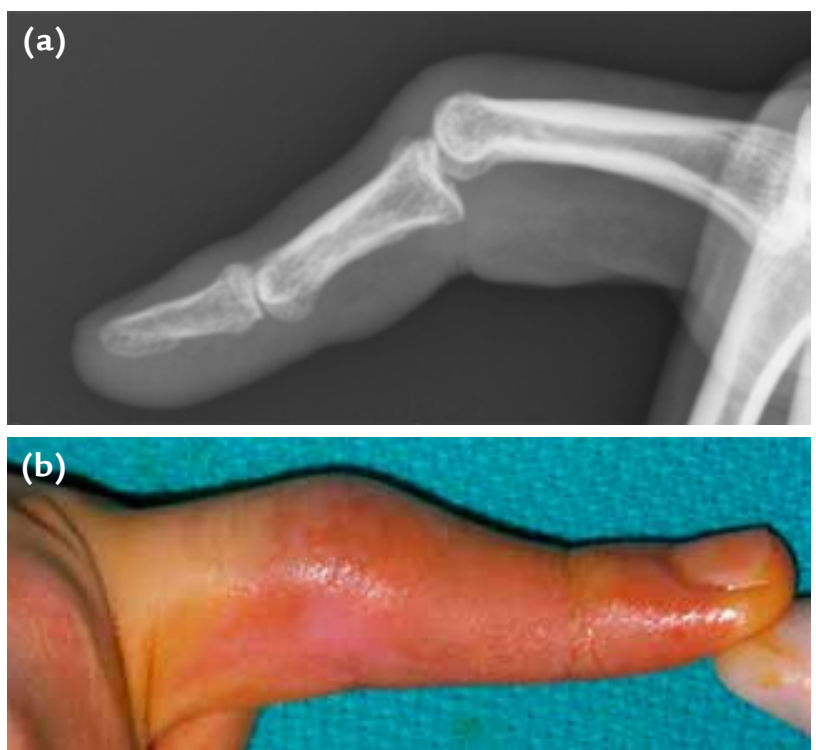

Şekil 6. a, b. Volar PIP çıkığı sonrasında gelişen düğme iliği deformitesinin radyolojik (a) ve klinik görünümü (b).

eklem redükte olamayabilir ve açık redüksiyon gerektirebilir. ${ }^{[13,14]}$ Kronik subluksasyon ya da instabilite, volar çıkıklarda dorsal ve laterale göre daha fazla görülmektedir; dorsal ve lateral çıkıklar sadece ligamentöz yaralanmalar iken, volar çıkıklara tendon yaralanmaları da eşlik edebilir. ${ }^{[15]}$ kollateral bağ üzerinde dönerek volare yer değiştirir. Döndürücü mekanizma sonucu gelen hastalarda, kapalı redüksiyon yaparken oluş mekanizmasındaki dönmenin tersi yönünde çevirerek redüksiyon yapmak gerekir. Eklem arasına santral slip, kopmuş kollateral bağ ya da lateral bandın girmesi nedeniyle 

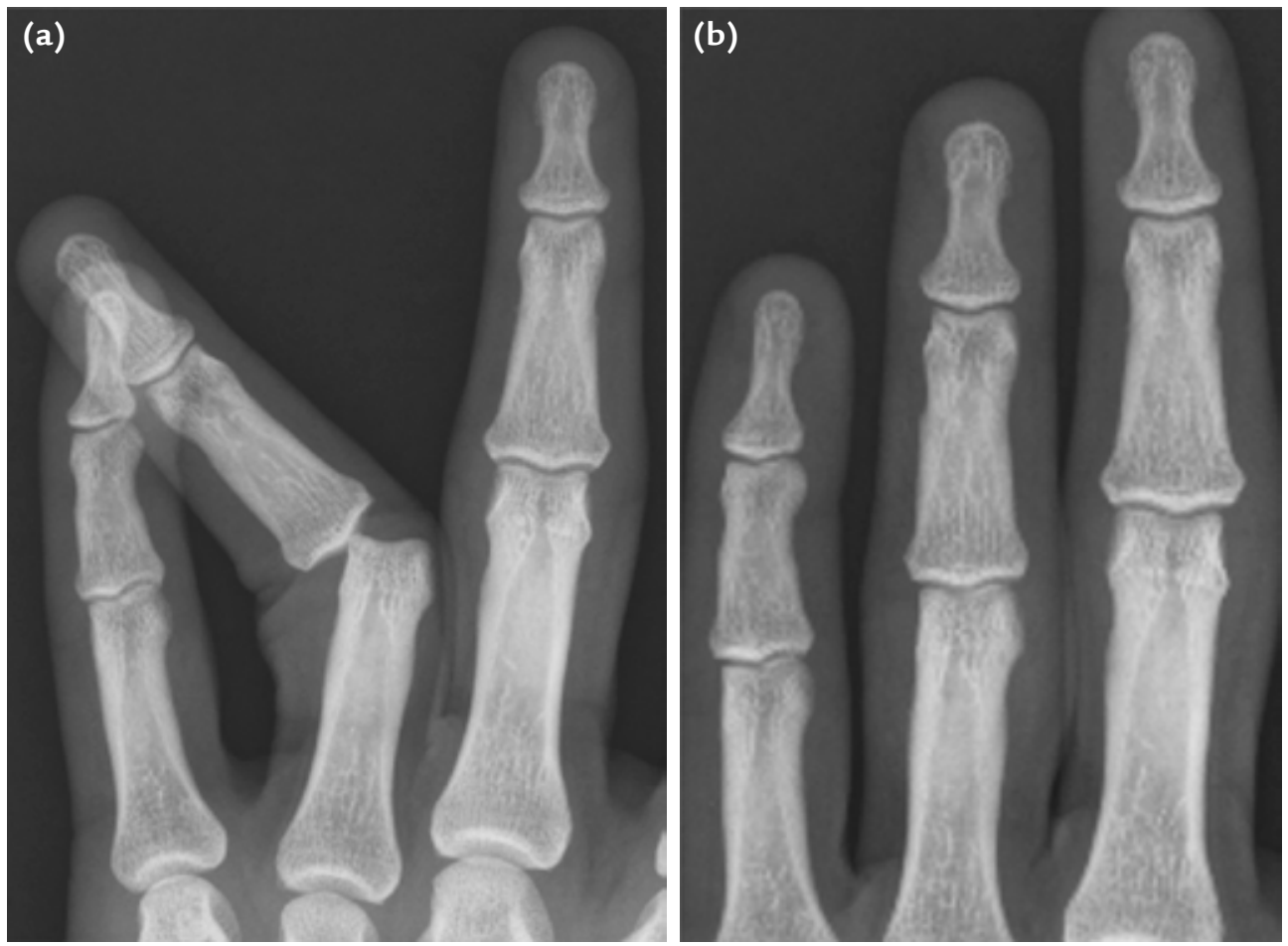

Şekil 7. a, b. Dördüncü parmakta laterale çıkık (a). Kapalı redüksiyon ile düzeltilmiş görünümü (b).

\section{Lateral PiP Çıkıkları}

Lateral çıkıklar, parmağa yandan gelen direkt kuvvetler sonrasında kollateral bağın proksimalden avulse olması ve kuvvetin devam etmesi ile volar plağın yaralanma tarafından başlayarak yırtılması sonucunda oluşur. ${ }^{[13,14]}$ Çıkık radyografik olarak tanı aldıktan sonra redüksiyon öncesi dijital blok uygulanmalı, redüksiyon mümkün olan en kısa sürede yapılmalıdır. Redüksiyon uzunlamasına çekme sonrasında orta falanksı çıktığı yönden bastırma ile yapılır. Çoğu zaman sadece çekme redüksiyon için yeterli olur (Şekil 7). Redüksiyon sonrasında ekstansiyonu $15^{\circ}$ bloklayan ateller kullanılır. DiP eklem atel içine alınmayabilir ve üç hafta içinde tedricen tam ekstansiyona getirilir. Üç haftalık atelleme sonrasında ek olarak kollateral bağın yaralanmış olduğu taraftaki parmağa üç hafta daha flaster tespit yapılması uygundur.

\section{METAKARPOFALANGEAL EKLEM ÇIKIKLARI}

Metakarpofalangeal (MP) eklemler elipsoid olup fibröz kapsül ile çevrelenmiştir. Radyal ve ulnar kollateral bağlar ile palmar bağlar stabilitesinden sorumlu önemli yapılardır. Palmar bağlar; kalın fibrokartilajinöz yapıda olup her iki kollateral bağı birbirine bağlar, ayrıca distalde proksimal falanksa sıkı bir şekilde yapışırken, proksimalde metakarp başlarına gevşek bağlanır. ${ }^{[16]}$

MP eklem dorsal ya da volare çıkabilir. Dorsale çıkıklar daha fazla görülmekte olup volare çıkıklar daha nadir görülür. Dorsale çıkıklar genellikle el üzerine düşme esnasında eklemin kuvvetli hiperekstansiyonu ile oluşur. Birinci parmaktan sonra en sık ikinci parmakta görülür. ${ }^{[17]}$ Çıkıklar basit ya da kompleks olabilir. Ciltte gamzeleşme, kompleks çıkıklarda görülürken basit çıkıklarda görülmez. Çıkık en iyi lateral grafide görülürken, eklem aralığının genişlemiş olması interpozisyonu düşündürmelidir. Basit çıkıklar, eklem arasına giren herhangi bir yapı olmadığı için kapalı yerleştirme ile tedavi edilebilir (Şekil 8). Kompleks çıkıklarda eklem arasına volar plak ve sesamoidler girebilir. Kaplan tarafindan tanımlanmış olan, volar plağın metakarp başından avulse olması ve eklem aralığına girmesi ile birlikte, metakarp başı volara deplase olur. Íkinci parmakta fleksör tendon ulnara, lumbrikal kas radyale deplase olarak, birlikte metakarp başını sıkıştırır ve redüksiyonu engeller. Beşinci parmakta ise fleksör tendon ve lumbrikal kas radyale, abduktor dijiti minimi ve fleksör dijiti minimi kasları ulnara deplase olarak kapalı redüksiyonu engeller. Rotator bağ dorsale, 

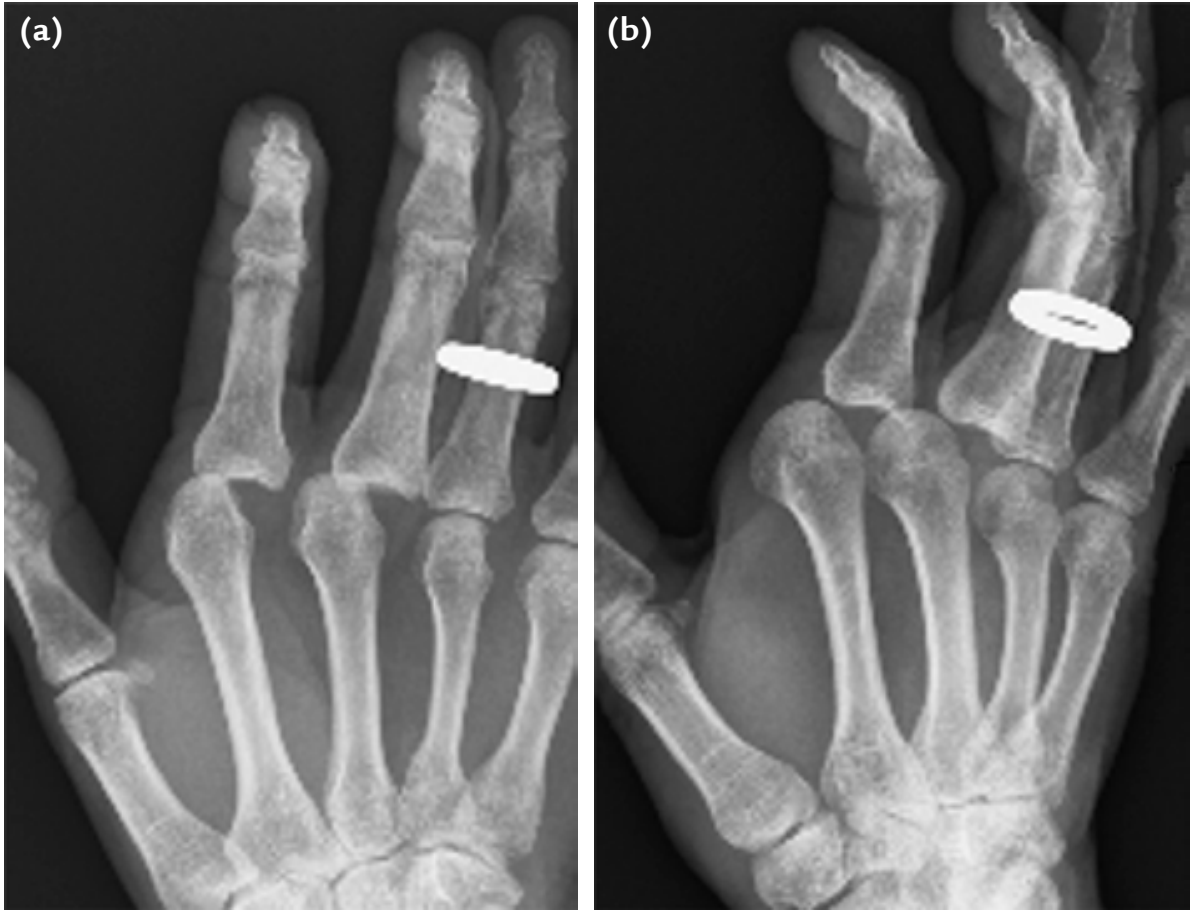

Şekil 8. a-d. İkinci, üçüncü MP eklem çıkıkları (a, b). Kapalı redüksiyon sonrası konsantrik redüksiyonun sağlandığı radyolojik görünüm (c, d).

\section{(c)}

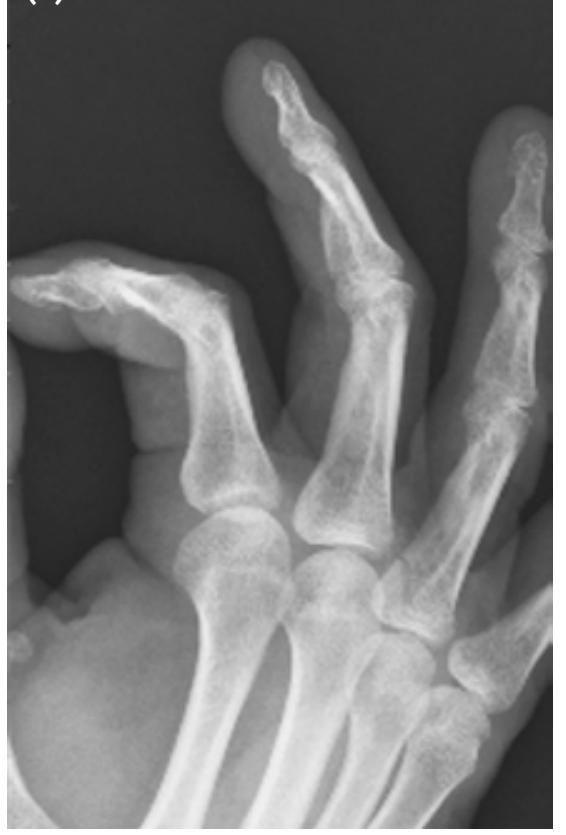

(d)

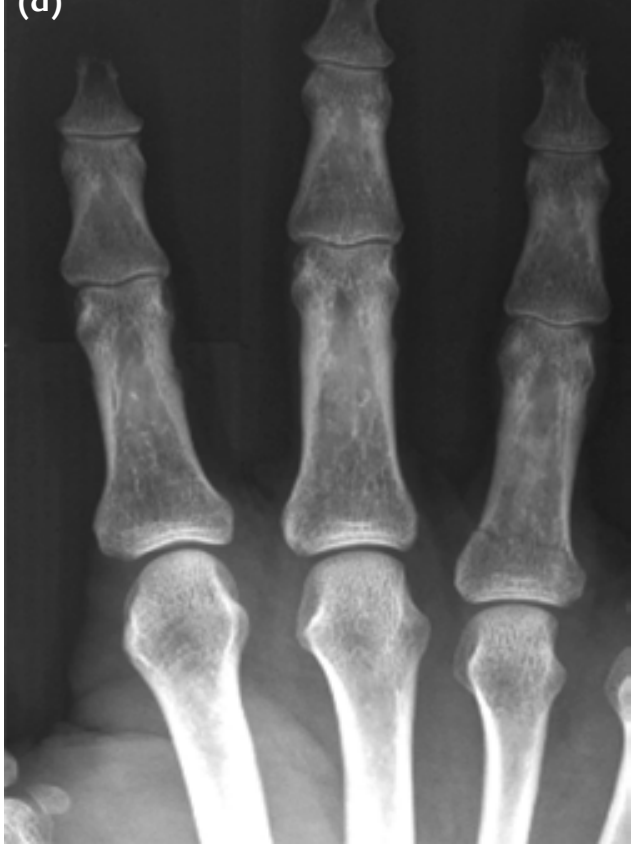

yüzeyel transvers metakarpal bağ proksimale deplase olur ve bu gibi durumlar açık redüksiyon gerektirebilir (Şekil 9). ${ }^{[18]}$ Açık redüksiyonu, palmardaki nörovasküler yapıların korunabilmesi, A1 pulleyin rotator ve transvers metakarpal bağlarının kolay kesilebilmesi için volarden önerenler olmakla birlikte, her zaman volar yaklaşım ile redüksiyon sağlanamayabilir. ${ }^{[19,20]}$ Bu gibi durumlarda ek dorsal yaklaşım ihtiyacı oluşur, ki bu da MP eklem sertliğine neden olabilir. Bazı yazarlar, dorsal yaklaşımın daha kolay redüksiyon ve daha iyi eklem hareketi sağladığını bildirmektedirler. ${ }^{[21,22]}$ 

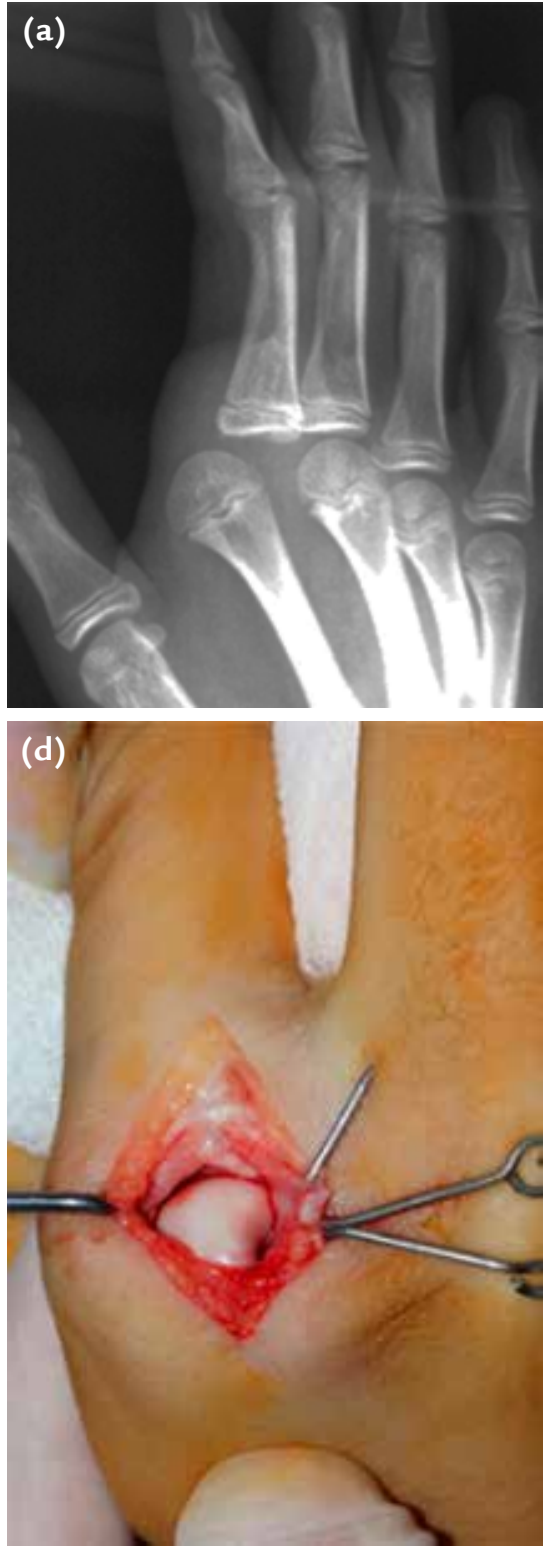
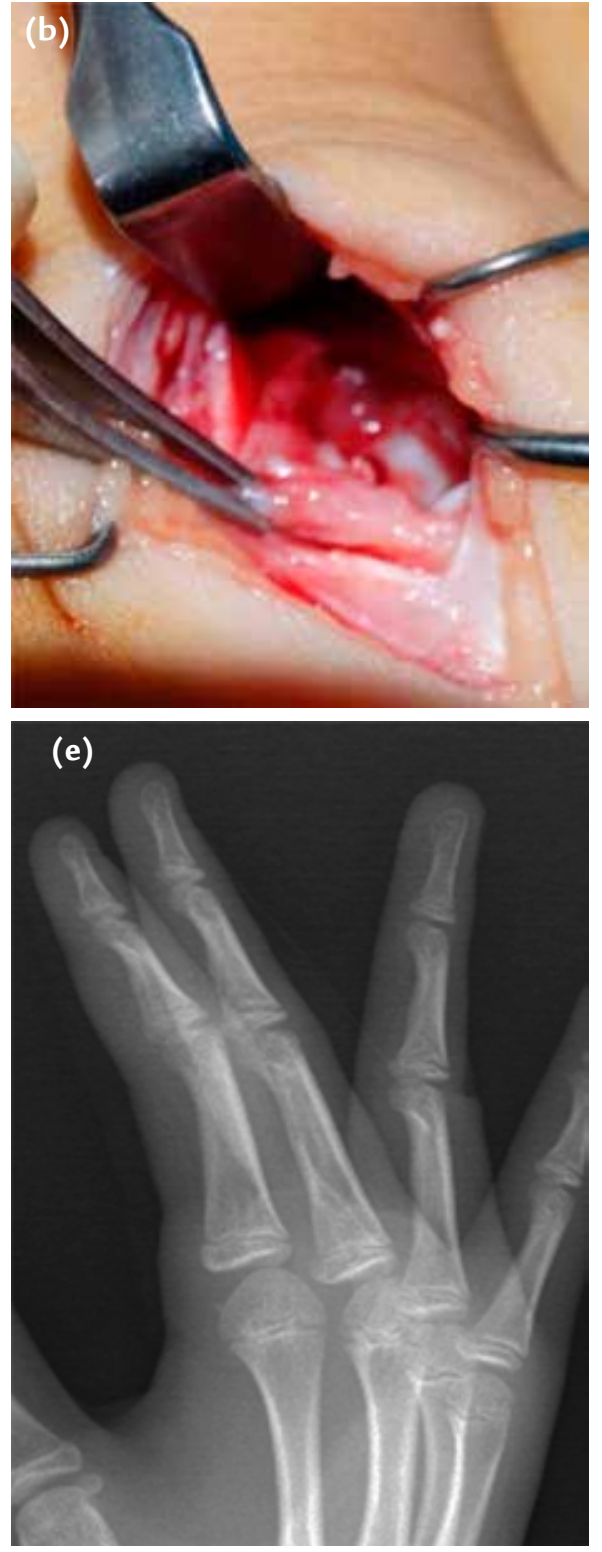

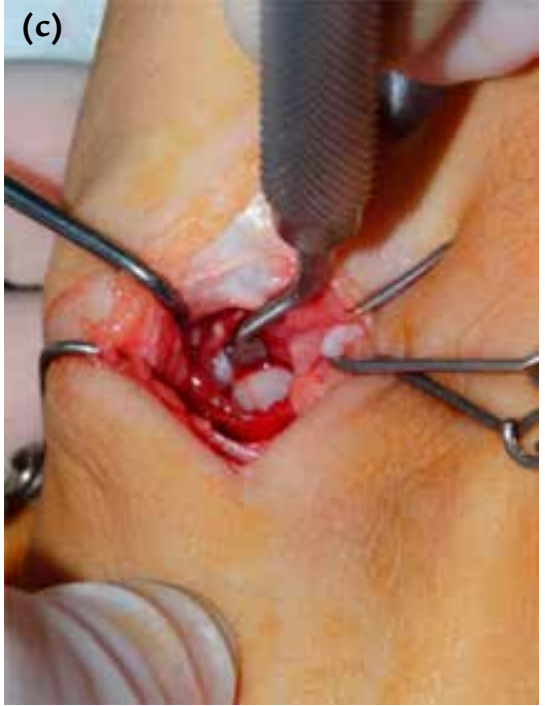

Şekil 9. a-e. İkinci MP eklemde başarısız kapalı redüksiyonun denemesi (a). Dorsal yaklaşım ile eklem hattına interpoze olan volar plakanın çıkarılması ve redüksiyonun sağlanması $(b-d)$. Açık redüksiyon sonrasında konsantrik redüksiyonun radyolojik görünümü (e).
İzole MP volara çıkıklar oldukça nadir görülür. Temel mekanizma zorlu hiperekstansiyondur; ayrıca, proksimal falanksın dorsalden volara translasyon zorlanmasıyla birlikte eklemin hiperfleksiyonu da volar çıkığa neden olabilmektedir. Kollateral bağlar sağlam kalabilmektedir. Ön arka grafide metakarp başı ve falanks proksimali üst üste binebilir, yan grafide ise diğer metakarpların başları çıkığı maskeleyebilir. Bu nedenle, oblik grafilerde çıkık daha net görülebilir. Kapalı redüksiyon manevrası, hafif fleksiyonda parmağı çekme ve çıkık proksimal falanksı volardan bastırma ile yapılabilir. Redüksiyon sonrasında eklem stabil ise yandaş parmağa tespit edilerek erken harekete başlanabilir. Eğer çıkık kapalı redükte olmaz ise açık redüksiyon yapilmalıdır. ${ }^{[22,23]}$

\section{BIRINCI KARPOMETAKARPAL EKLEM ÇIKIKLARI}

Birinci karpometakarpal eklem çıkıkları çok nadir görülür. Birinci parmak metakarpına fleksiyon pozisyonundayken aksiyel kuvvetlerin etki etmesi sonucu oluşur ve çoğunlukla dorsal yönde gerçekleşir. Eklemin tekrarlayan çıkıkları travmatik veya idiyopatik olabilir. Akut çıkıklar, anterior oblik bağın distal 
ayrışmasıyla birlikte, dorsoradyal bağın yırtığından tüm bağların yırtığına kadar geniş bir yaralanma yelpazesine neden olabilir. Anterior oblik bağın sağlam ancak ayrışmış olduğu çıkıklarda, birinci parmak ekstansiyon ve pronasyona getirilmeli ve perkütan K-telleri ile tespiti sağlanmalıdır. Tüm bağların yırtık olduğu olgularda ise eklem instabil olacağından, açık redüksiyon ve tespit sonrası bağ rekonstrüksiyonu uygun olacaktır. ${ }^{[24]}$ Bazı çalışmalarda açık cerrahilere ve bağ rekonstrüksiyonlarına ihtiyaç olmadığı ve kapalı redüksiyon ve perkütan K-teli tespitinin yeterli olacağı belirtilmiştir. ${ }^{[25]}$ Ancak yeni çalışmalarda, akut yaralanma olgularında kapalı redüksiyonu takiben başparmağa hafif abduksiyon ile alçı uygulaması ve eklem ilişkisinin bozulmadığı durumlarda 4-6 hafta süre ile takip önerilmektedir. Eklem ilişkisi uygun çekilmiş direkt grafilerle veya bilgisayarlı tomografi (BT) ile kesinleştirilmelidir. Eklem instabilitesi var ise kapalı redüksiyon ve K-teli tespiti önerilmektedir. Kapsülorafi ve bağ rekonstrüksiyonu ise bahsedilen tedavi prosedürlerinin yetersiz kaldığı olgulara saklanmalıdır. ${ }^{[26]}$

\section{KARPOMETAKARPAL ÇIKIKLAR}

Eyer tipi eklemlerden olan karpometakarpal (KMK) eklemin çıkıkları, nadir gözlenen çıkıklardandır. Bu eklemin ulnar yarısı daha hareketli özelliğe sahiptir. ${ }^{[27]}$ Üçüncü metakarpın kapitatla yaptığı eklem ise daha proksimal yerleşimli olmasından ötürü anahtar taşı niteliğindedir. Tüm el bileği çıkıkları gibi KMK eklem çıkıkları da yüksek enerjili travmalar sonucu dorsal veya palmara olabilmekte ve ek yaralanmalarla birliktelik gösterebilmektedir. ${ }^{[28]}$

Görüntülemede, öncelikle ön-arka ve yan grafiler değerlendirilir. Ön arka grafilerde Gilula çizgilerindeki bozukluk ve yan grafilerde dorsal-palmar yöne çıkıklar not edilir. ${ }^{[29]}$ Karpal kemik kırıkları gibi ek yaralanmaları değerlendirmek amacıyla BT çekilmesi uygun olacaktır.

$\mathrm{Bu}$ yaralanmalar kapalı redüksiyon ve alçılama ile takip edilebilse de, sonuçları yüz güldürücü değildir. Dolayısıyla, tercih edilmesi gereken en uygun yöntem açık redüksiyon ve K-teli ile tespit olmalıdır. Bu sayede çıkığın redüksiyonu ve tespiti direkt olarak değerlendirilebilir. Tespitte öncelik, anahtar taşı olan 3. KMK ekleme verilmelidir. ${ }^{[30]}$

\section{KARPAL ÇIKIKLAR}

Elin kompleks yaralanmaları arasında yer alan karpal çıkıklar, oluş mekanizmalarına göre üç alt grupta incelenebilir. Bunlar;
1) Perilunat yaralanmalar

a) Küçük ark yaralanmaları (perilunat ve lunat çıkıkları)

b) Büyük ark yaralanmaları (perilunat kırıklı-çıkıkları)

2) Radyokarpal çıkıklar

3) Aksiyel çıkıklar

\section{PERILUNAT YARALANMALAR}

Yüksek enerjili travmalar sonucu oluşan perilunat yaralanmalar, karpal yaralanmaların yaklaşık \%7-10'luk kısmını oluşturur. ${ }^{[31,32]}$ Tekil yaralanmalar olabileceği gibi, çoklu travmanın bir parçası olarak yer alabilir. Vital bulguların stabil olmadığı politravmalı hastalarda da sıklıkla atlanabilir.

Karpal kemikler yerleşimlerine göre iki sıraya bölünmüştür. Proksimal sıra skafoid, lunatum, trikuetrum, ve pisiform; distal sıra ise trapezium, trapezoideum, kapitatum ve hamatum kemiklerinden oluşmaktadır. Distal karpal kemik sırası metakarpal kemiklerle sıkı bir şekilde bağlı iken; proksimal sıra kemikler radius ve distal sıra kemikleri arasında sıkışmış durumdadır ve hareketli özelliğinden dolayı instabil bölge olarak değerlendirilmektedir. Bu özellik lezyonların çoğunlukla proksimal sırada oluşmasına neden olmaktadır. ${ }^{[33]}$

Yaralanma mekanizmasına göre perilunat yaralanmalar; a) yaralanma yönüne göre ve b) yaralanma büyüklügüü ve çıkığın yönüne göre olmak üzere iki farklı şekilde sınıflandırılır. Yaralanma yönüne göre ekstansiyon tipinde karpal kemikler dorsale doğru lukse olur ve "dorsal perilunat çıkıklar" adını alır. Fleksiyon tipinde ise karpal kemikler palmara doğru lukse olur ve "palmar perilunat çıkılar” olarak değerlendirilir. Yaralanma büyüklügüü ve çıkığın yönüne göre de yaralanmalar kendi içinde "küçük ark" ve "büyük ark" olmak üzere ikiye ayrılır. İzole ligamentöz çıkıklar, lunatum çevresinde olur ve küçük arkı oluştururken, kemik ve bağ tutulumlu çıkıklar lunatumdan uzaklaşarak büyük arkı oluşturur (Şekil 10).

\section{Yaralanma mekanizması}

El bilek eklemine etki eden yüksek enerjili ekstansiyon ve fleksiyon kuvetlerine ilaveten karpal kemiklerin pronasyon veya supinasyona yönelimi perilunat çıkıklara veya kırıklı çıkıklara yol açmaktadır. Bu kuvvetler, kapitatum ve lunatum arasındaki bağların diğer karpal bağlara kıyasla zayıf olması sonucunda, bu iki kemik arasında ayrışmaya neden olur. Ekstansiyon veya fleksiyon tipi yaralanmalar karpal kemiklerin lunatuma göre yer değiştirmesine göre tanımlanır. ${ }^{[31]} \mathrm{Bu}$ mekanizma yardımıyla karpal kemikler arası bağlarda 

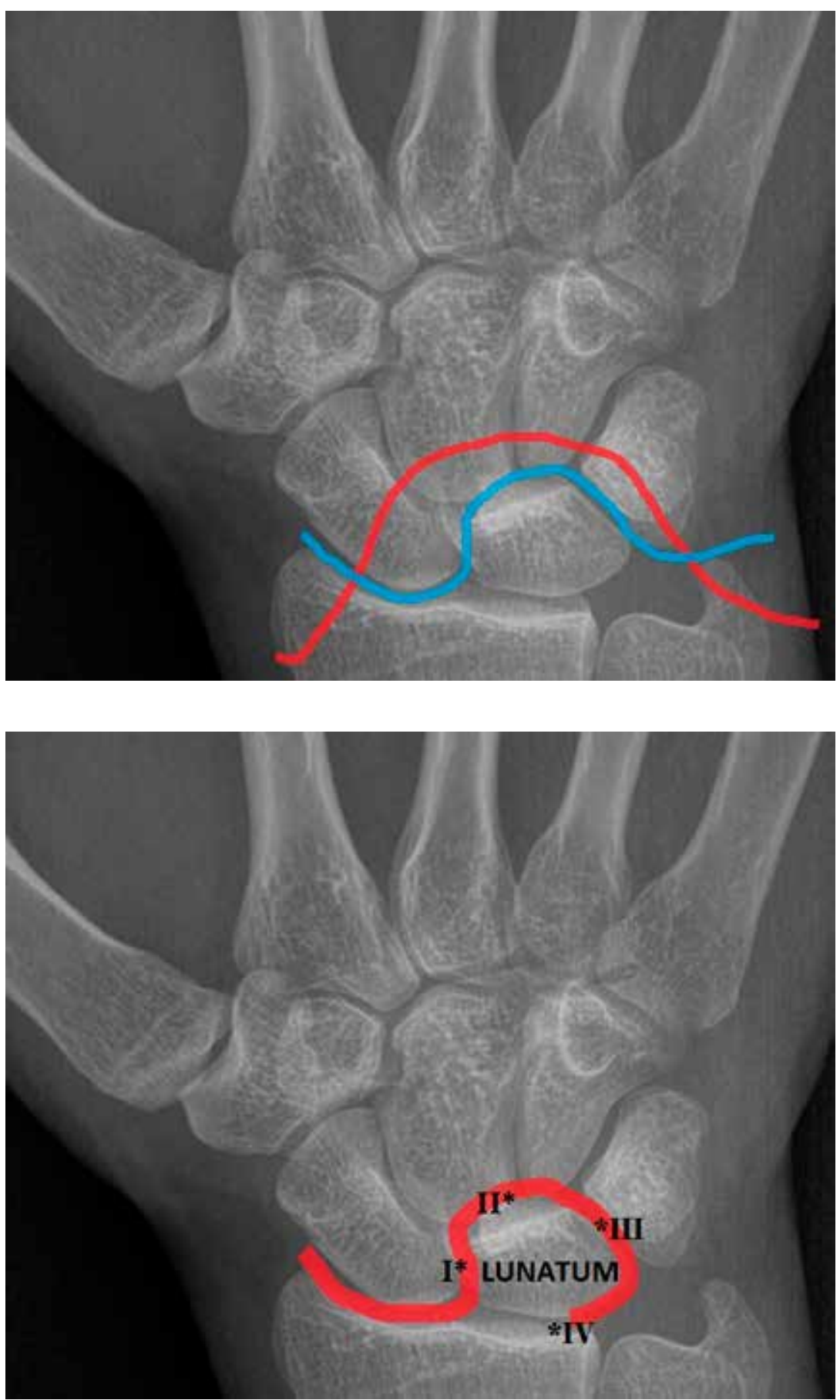

Şekil 10. Mavi çizgi küçük arkı gösterir; perilunat bağ yaralanmalarında bozulur. Kırmızı çizgi büyük arkı gösterir; perilunat kırıklı çıkıklarda bozulur.
Şekil 11. Mayfield'e göre yaralanmanın sıralanması. olduğu gibi karpal sıralar arası bağlarda yaralanma meydana gelebilir. Önceden bahsedildiği üzere, fleksiyon-ekstansiyon kuwetlerine ek karpal kemiklerin rotasyona uğraması karpal bağ yaralanmalarının sırasını ve boyutunu etkilemektedir. Bu kuvvetleri ve seyri inceleyerek Mayfield yaralanmanın boyutunu ve seyrini dört evreye bölmüştür (Şekil 11) ${ }^{[34]}$ :
Evre I: Skafolunat bağ yırtığı

Evre II: + Radyoskafokapitat bağ yırtığı

Evre III: + Lunotrikuetral bağ yırtığı

Evre IV: Lunatumun çıkığı 

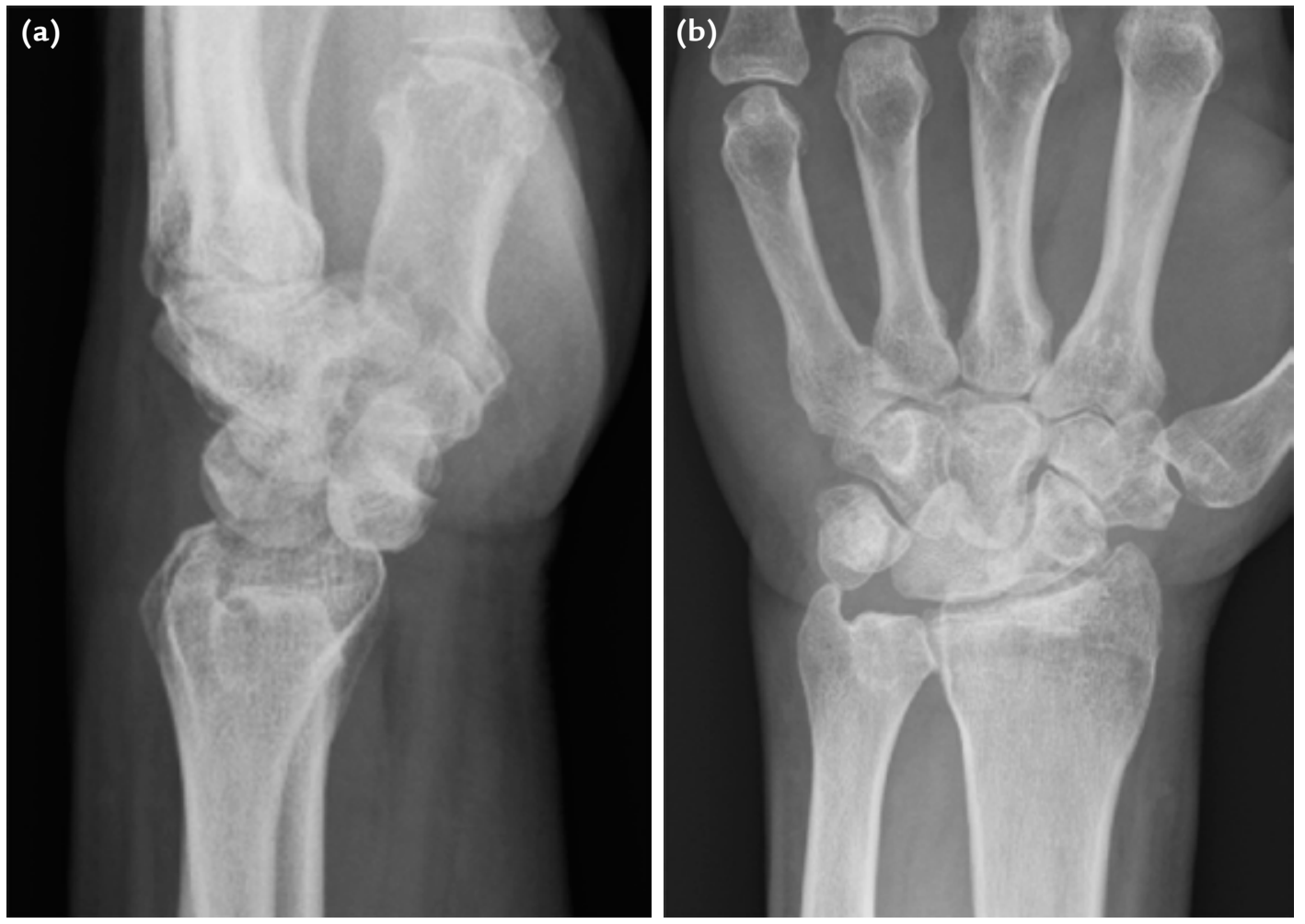

Şekil 12. a, b. Üç aylık gözden kaçmış lunatum palmar çıkığı.

Perilunat yaralanmaların direkt grafilere göre bir sınıflaması da Herzberg tarafindan 1993 yılında yapılmıştır. ${ }^{[35]}$ Herzberg bu sınıflamada ön-arka grafileri değerlendirmede çevre kemik kırıklarını dikkate almış, izole perilunat çıkıklar ve perilunat kırıklı çıkıklar (skafoid kırığı birlikteliği dikkate alınmalıdır) olarak ikiye bölmüştür. Yan grafilerin incelenmesinde ise lunatumun komplet çıkıkları öncelikle palmar ve dorsal olarak ikiye bölünmüş ve her ikisi de kendi içlerinde lunatumun yönelimine göre dörde ayrılmıştır. Evre I'de lunatumun dizilimi normalken, Evre II'de $90^{\circ}$ 'den az rotasyon, Evre III'te $90^{\circ}$ 'den fazla rotasyon mevcut fakat radiusla temas devam etmekte, Evre IV'te ise yumuşak doku bağlantısı olmaksızın total dislokasyon mevcuttur.

\section{Klinik bulgular}

Perilunat çıkıkların çoğunlukla spesifik bir muayene bulgusu yoktur. Şişlik, belirgin eklem hareket kısıtlılıkları görülebileceği gibi, ayrıca dizilim bozuklukları da karpal yaralanmalara işaret etmektedir. Lunatumun karpal tünele doğru çıkı̆̆ına sekonder gelişebilecek median sinir basısına bağlı bulgular ortaya çıkabilir. Atlanmış ve yeteri kadar önemsenmemiş olgularda kronik perilunat instabilite ve artroz gelişebilir. (Şekil 12).

\section{Tanı-değerlendirme}

Perilunat yaralanma şüphesi bulunan bir hastada, öncelikli olarak ön-arka ve yan direkt grafileri elde edilmelidir. Önceden belirttiğimiz açıların ölçülebilmesi açısından tam yan çekilmiş el bileği grafisi önem arz etmektedir. Direkt grafilerin yanında BT görüntülemeleri de, büyük ark yaralanmaları gibi ek yaralanmaların değerlendirilmesi açısından mutlaka istenmelidir.

Ön-arka grafilerin değerlendirmesinde Yin ve Gilula ${ }^{[29]}$ tarafından tanımlanmış olan üç çizginin iyi tanınması gerekir. Proksimal karpal sıranın proksimal sınırı 1. çizgiyi oluştururken, distal sınırı 2. çizgiyi oluşturur. Distal karpal sıranın proksimal sınırı ise 3 . çizgiyi oluşturur. Sağlıklı bir el bileğinde, bahsi geçen bu üç çizgi birbiriyle uyumlu olarak bir kavis oluşturur (Şekil 13). Meydana gelen yaralanmalarda ise bu hatlarda bozulmalar gözlenir. Yine ön-arka grafilerde lunatum eşkenar dörtgen görünümündeyken, çıkıklarda çoğunlukla üçgen formu gözlenir.

Akut dönemde manyetik rezonans görüntüleme kırık veya kemik ödemi arasında keskin çizgilerle ayrım sağlamasa da, kronik dönemde kıkırdak değerlendirilmesi açısından yararlı olacaktır. 


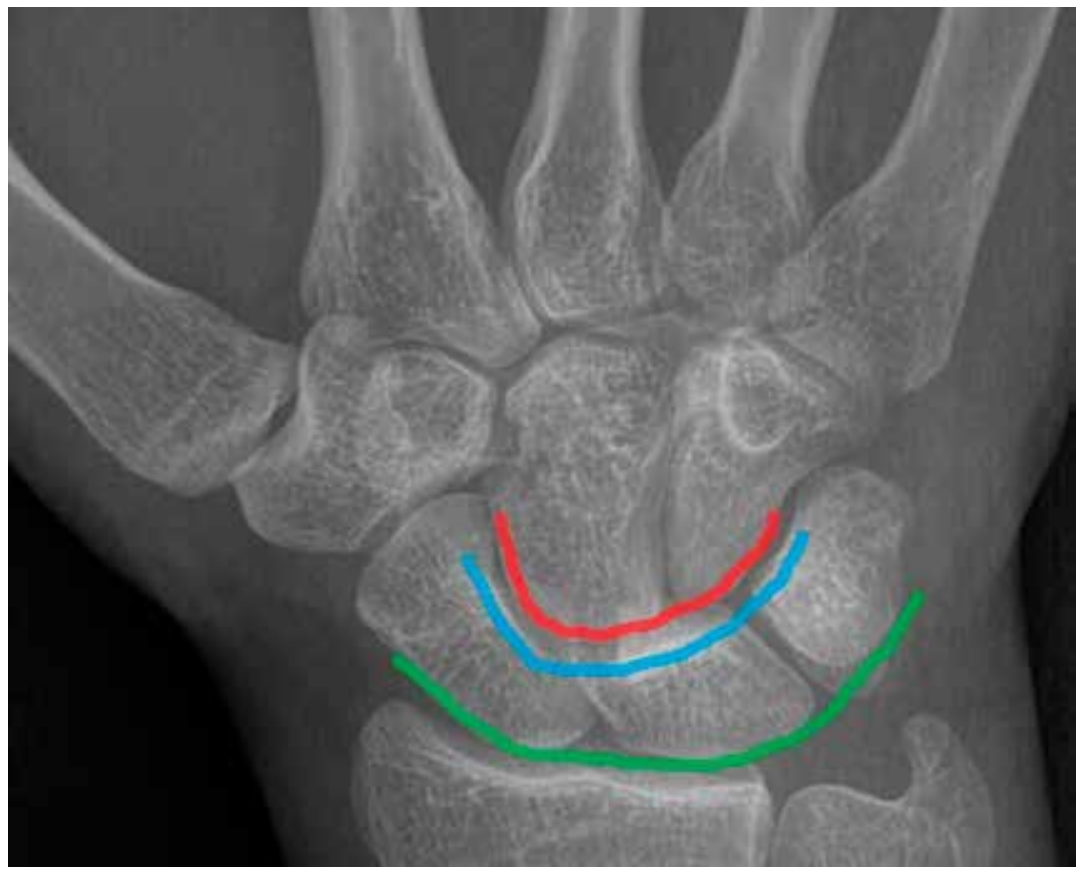

Şekil 13. Gilula çizgileri.

\section{Tedavi}

Akut perilunat yaralanmalarda, öncelik çıkığın yerine yerleştirilmesine verilmelidir. Çıkığın redükte edilmesini takiben tespit veya rekonstrüksiyon ihtiyacı değerlendirilmelidir. Bu işlemlerin mümkün olan en kısa sürede uygulanmasında yarar vardır. Kapalı manevralarla redüksiyon ve tespit çoğu zaman başarısız olmakta veya takibinde yüksek komplikasyonlar gözlenmektedir. Bu durumda şüphede kalmadan açık redüksiyon tercih edilmelidir. Uygulanacak cerrahide öncelikli olarak dorsal girişim kullanılmalıdır ve bu çoğu zaman yeterli olur. Cerrahi müdahalenin temeli, mevcut kırıkların uygun implantlar kullanılarak tespiti ve gerekli ise bağ rekonstrüksiyonudur. Kırık tespitinde sıklıkla başsız kompresyon vidaları kullanılır. Kırık tespitinin ardından eklem dizilimi düzgün bir şekilde sağlanmalı ve uygun pozisyonda K-telleri yardımıyla tespit yapılmalıdır (Şekil 14). Bağ onarı$\mathrm{mı}$, yaralanmanın yönü ve instabiliteye göre olmalıdır. Kullanılacak yöntem, bağların direkt tamiri veya osteosütür tekniği ile olmalıdır. Eksternal fiksatör ise, stabilitenin yetersiz olduğu olgularda ek yöntem olarak tercih edilmelidir.

Perilunat yaralanmalarının yüksek enerjili travmalar sonucu oluştuğu unutulmamalıdır. Cerrahi zamanlama planlanırken, travma sonucu yumuşak doku değerlendirilmeli, şişliği fazla olan olgularda çıkığın redüksiyonu sonrası geçici tespit ve gerekli durumlarda eksternal fiksatör uygulaması ile, kalıcı cerrahi yumuşak doku sorunlarının ortadan kalkmasına kadar bekletilebilir. Ameliyat sonrası kontrol direkt grafilerin yanında, olası implant yerleşim ve dizilim bozukluklarını değerlendirmek amacıyla BT çekilmesi önemlidir. Cerrahi sonrası 6-8 hafta süresince 1. parmağı da stabilize eden kısa kol alçı uygulaması yapılır ve sonrasında K-telleri çıkartılır ve eklem hareket açıklığı kazanılmaya çalışılır.

\section{RADYOKARPAL ÇIKIKLAR}

Radyokarpal çıkıklar nadir görülen yaralanmalardır. Perilunat yaralanmalar gibi yüksek enerjili travmalar sonucu görülür ve çoğunlukla dorsal olarak gözlenir. Etiyolojisinde trafik kazaları ve yüksekten düşme bulunmakla beraber, hiperekstansiyondaki karpal kemiklere rotasyonel kuvvetlerin etki etmesiyle oluşur. ${ }^{[36]}$

Tanı için öncelikle direkt grafiler tercih edilir. Direkt grafi bulgularına göre radyokarpal çıkıklar iki gruba ayrılır: 1) Tip 1 çıkıklar saf ligamentöz lezyonlar olarak gözlenir. El bileğinin dorsalinde radyoskafoid bağ ve kısa radyokarpal bağlar yaralanır. Bu yaralanmalar çoğunlukla instabildir ve radyal stiloid veya küçük kortikal parça avulsiyonu eşlik edebilir. 2) Tip 2 çıkıklarda ise radyal stiloid skafoid eklem yüzünün üçte birinden fazlasını kapsayacak şekilde horizontal kırık mevcuttur. Radyokarpal bağlar stiloide yapıştığından 

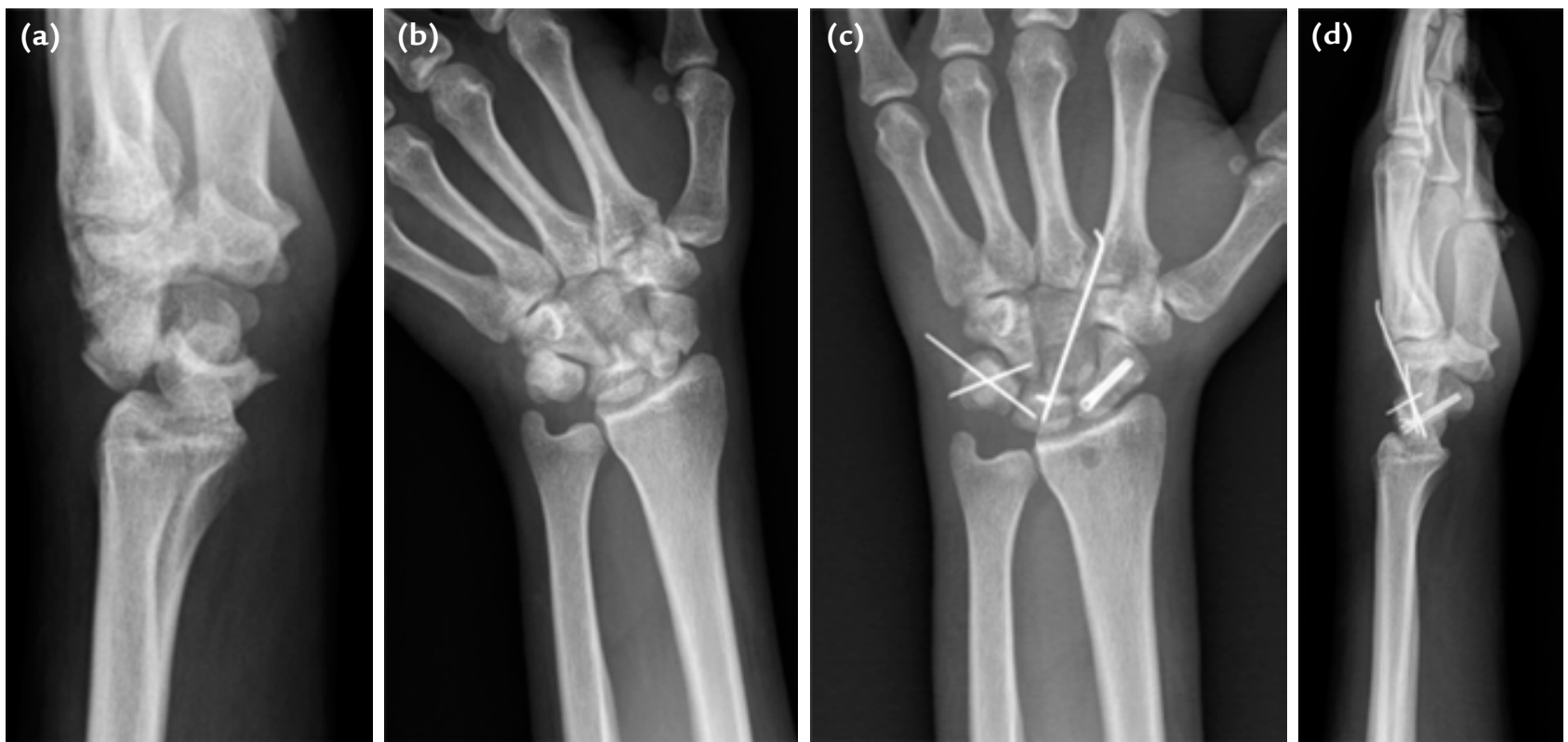

Şekil 14. a-d. Transskafoid perilunat kırıklı çıkık yan ve ön-arka grafileri (a, b). Açık redüksiyon ile skafoidin başsız vida ile çıkık eklemlerin K-telleri ile tespitinin ameliyat sonrası grafileri (c, d).

dolayı bu parçanın tespiti el bileğine stabilitede katkı sağlayacaktır. Yaralanma bölgesine yakın lokalizasyonu nedeniyle, perilunat yaralanmalarda olduğu gibi, median sinir yaralanmaları veya basısı gözlenebilir. ${ }^{[37]}$

\section{Tedavi}

Radyokarpal çıkıklar redüksiyon sonrası nadiren stabilite gösterir. Dolayısıyla bu tip yaralanmalarda redüksiyon sonrası geçici K-telleri ile tespit sıklıkla önerilmektedir. Açık kırıklı çıkıklar, nörovasküler yaralanmalar ve redükte edilemeyen çıkıklarda cerrahi endikasyon mevcuttur. Tedavinin hedeflerini Dumontier üç basamakta değerlendirmiştir. Bunlar: 1) radyokarpal uyumun sağlanması, 2) intrakarpal lezyonları tanımak ve tedavi etmek, ve 3) kemik-bağ yaralanmalarını stabil olarak tamir etmektir. ${ }^{[36]}$

Radyokarpal çıkıklara sıklıkla palmar yaklaşımla girilir ve traksiyon uygulanarak redüksiyon sağlanır. Eklem dikkatlice değerlendirildikten ve temizlendikten sonra, kırık var ise (Tip 2) tespit edilir. Ardından kapsül ve bağlar sütür ankorlar vasıtasıyla radyal stiloide tespit edilir. Trianguler fibrokartilaj kompleksin (TFCC) yaralandığı ve radyoulnar instabilitenin bulunduğu olgularda TFCC'nin onarımı ve K-teli tespiti gerekir. Palmar yaklaşımın yardımıyla, ayrıca median ve ulnar sinir dekompresyonu sağlanabilir. ${ }^{36]}$

Açık kırıklar, saf ligamentöz yaralanmalar (Tip 1), sinir ve interkarpal yaralanmaların varlığı, radyokarpal çıkıkların tedavisinde kötü prognoz kriterlerini oluşturur. İnstabilitenin devam etmesi ve hareket kısıtlılığı, radyokarpal çıkıkların en sık görülen komplikasyonlarındandır. Bunların dışında; el bileği artrozu, septik artrit, tendon hasarları diğer görülebilen komplikasyonlar içindedir.

\section{AKSIYEL ÇIKIKLAR}

El bileği aksiyel karpal kırıkı çıkıkları, radyal yarı ve ulnar yarı olmak üzere iki grupta ayrılır. Radyal yarı aksiyel kırıklı çıkıklarda, yaralanma trapezium çevresinde gerçekleşir ve 1. parmak kompleksini karpal kemiklerden ayırır. Ulnar yarı aksiyel çıkıklarda ise yaralanma triquetrum çevresinde gelişmektedir. Bazı olgularda ulnar ve radyal yarı yaralanmaları birlikte görülebilmektedir.

Nadir olan aksiyel kırıklı çıkıklar arasında ulnar yarı yaralanmaları en sık görülür. Bu çıkıklara, distal karpal sıraya etki eden dorsal-palmar yönlü kompresyon kuvvetleri neden olur. Temel patoloji, perilunat yaralanmalarda proksimal sırada iken, aksiyel karpal çıkıklarda distal sıra ve metakarpal ark arasında yer almaktadır. Aksiyel yaralanmaların büyük çoğunluğu ezici-patlayıcı tarzda olduğu için açık kırıklı çıkıklara dahil olmaktadır. Direkt grafilerde Gilula çizgilerini değerlendirmek gerekir, fakat tanıyı konvansiyonel grafilerle koymak zor olacağından, tanı için BT görüntüleme değerlidir. Açık aksiyel karpal çıkıklarda öncelik, yıkama ve debridmana verilmelidir ve takiben karpal 
tünele gevşetme uygulamak gerekecektir. Ardından dorsal yaklaşımla açık redüksiyon ve K-teli ile tespit yapılmalıdır. ${ }^{[38]}$ Distal sıra ve intermetakarpal bağların tamiri gerekli görülmemektedir. Fakat, yaralanmanın proksimal sıraya ilerlediği gözlendiği takdirde, skafolunat bağ tamiri uygulanmalıdır. Kapalı aksiyel karpal çıkıklar çoğunlukla yoğun ödem ve şişlik ile başvurur. Bu hastalarda da, dorsal yaklaşımla açık redüksiyon ve K-telleri ile tespit önemlidir. Bu hastalarda, median sinir sıkışmasına ait semptomlar ilerleyici olduğu zaman dekompresyon uygun olacaktır. Kapalı yaralanmaların tedavi sonuçları, yumuşak doku hasarının az olmasından dolayı açık yaralanmalara göre daha iyidir. ${ }^{[39]}$

Sonuç olarak el ve el bileği çıkıklarında yaralanmaları değerlendirmek için el ve el bileği anatomisine hakim olmak gerekir. Bu eklemlerin çıkıkları bir bütün olarak ele alınmalı, yaralanması muhtemel bağlar, tendonlar, kırık parçalar dikkatlice değerlendirilmelidir. Tedavi mümkün olan en erken dönemde yapılmalı, redüksiyonun kapalı yöntemler ile sağlanamadığı durumlarda cerrahi tedavi uygulanmalı, fonksiyonların erken kazanılması amacıyla erken harekete izin veren yöntemler tercih edilmelidir.

\section{KAYNAKLAR}

1. Craig SM. Anatomy of the joints of the fingers. Hand Clin 1992;8(4):693-700.

2. Chen SH, Chan SY, Tien HY. Differences between dorsal and volar dislocations of the distal interphalangeal joint of fingers: a report of 30 cases. J Hand Surg Eur Vol 2017;42(2):197-8. Crossref

3. Thayer DT. Distal interphalangeal joint injuries. Hand Clin 1988;4(1):1-4.

4. Morisawa $\mathrm{Y}$, Ikegami $\mathrm{H}$, Izumida R. Irreducible palmar dislocation of the distal interphalangeal joint. J Hand Surg Eur Vol 2006;31(3):296-7. Crossref

5. Abouzahr MK, Poblete JVP. Irreducible dorsal dislocation of the distal interphalangeal joint: case report and literature review. J Trauma 1997;42(4):743-5. Crossref

6. Bailie DS, Benson LS, Marymont JV. Proximal interphalangeal joint injuries of the hand. Part I. Anatomy and diagnosis. Am J Orthop (Belle Mead NJ) 1996;25(7):474-7.

7. Kiefhaber TR, Stern PJ, Grood ES. Lateral stability of the proximal interphalangeal joint. J Hand Surg Am 1986;11(5):661-9. Crossref

8. Joyce KM, Joyce CW, Conroy F, Chan J, Buckley E, Carroll SM. Proximal interphalangeal joint dislocations and treatment: an evolutionary process. Arch Plast Surg 2014;41(4):394-7. Crossref

9. Bindra RR, Foster BJ. Management of proximal interphalangeal joint dislocations in athletes. Hand Clin 2009;25(3):423-35. Crossref

10. Freiberg A. Management of proximal interphalangeal joint injuries. Can J Plast Surg 2007;15(4):199-203. Crossref

11. Takami H, Takahashi S, Ando M. Irreducible open dorsal dislocation of the proximal interphalangeal joint. Arch Orthop Trauma Surg 2001;121(4):232-3. Crossref
12. Kung J, Touliopolis S, Caligiuri D. Irreducible dislocation of the proximal interphalangeal joint of a finger. J Hand Surg Br 1998;23(2):252. Crossref

13. Eaton RG, Littler JW. Joint injuries and their sequelae. Clin Plast Surg 1976;3(1):85-98.

14. Saitta BH, Wolf JM. Treating Proximal Interphalangeal Joint Dislocations. Hand Clin 2018(2):34:139-48. Crossref

15. Tohyama M, Konishi S. Irreducible Volar Rotatory Subluxation of the Proximal Interphalangeal Joint of the Finger. J Hand Surg Asian Pac Vol 2018;23(1):111-5. Crossref

16. Minami A, An KN, Cooney WP, Linscheid RL, Chao EYS. Ligamentous Structures of the Metacarpophalangeal Joint: A Quantitative Anatomic Study. J Orthop Res 1983;1(4):3618. Crossref

17. Wood MB, Dobyns JH. Chronic, complex volar dislocation of the metacarpophalangeal joint. J Hand Surg Am 1981(1):6:736. Crossref

18. Kaplan EB. Dorsal dislocation of the metacarpophalangeal joint of the index finger. J Bone Joint Surg Am 1957(5):39:1081-6. Crossref

19. Durakbasa O, Guneri B. The volar surgical approach in complex dorsal metacarpophalangeal dislocations. Injury 2009:40(6):657-9. Crossref

20. Mudgal CS, Mudgal S. Volar open reduction of complex metacarpophalangeal dislocation of the index finger: a pictorial essay. Tech Hand Up Extrem Surg 2006;10(1):31-6. Crossref

21. Patterson RW, Maschke SD, Evans PJ, Lawton JN. Dorsal approach foropen reduction of complexmetacarpophalangeal joint dislocations. Orthopedics 2008(11):31:1099-102. Crossref

22. , Vadala CJ, Ward CM. Dorsal Approach Decreases Operative Time for Complex Metacarpophalangeal Dislocations. J Hand Surg Am 2016:41(9):e259-62. Crossref

23. Dinh P, Franklin A, Hutchinson B, Schnall SB, Fassola I. Metacarpophalangeal Joint Dislocation. J Am Acad Orthop Surg 2009;17(5):318-24. Crossref

24. Strauch RJ, Behrman MJ, Rosenwasser MP. Acute dislocation of the carpometacarpal joint of the thumb: an anatomic and cadaver study. J Hand Surg Am 1994;19(1):93-8. Crossref

25. Sim E. Die Daumensattelgelenkverrenkung als seltene Sportverletzung. Sportverletz Sportschaden 1990;4(2):92-5. Crossref

26. Bosmans B, Verhofstad MH, Gosens T., Traumatic thumb carpometacarpal joint dislocations. J Hand Surg Am 2008;33(3):438-41. Crossref

27. El-Shennawy M, Nakamura K, Patterson RM, Viegas SF. Threedimensional kinematic analysis of the second through fifth carpometacarpal joints. J Hand Surg Am 2001;26(6):10305. Crossref

28. Kumar R, Malhotra R. Divergent fracture-dislocation of the second carpometacarpal joint and the three ulnar carpometacarpal joints. J Hand Surg Am 2001;26(1):123-9. Crossref

29. Gilula LA. Carpal injuries: analytic approach and case exercises. AJR Am J Roentgenol 1979;133(3):503-17. Crossref

30. Pundkare GT, Patil AM. Carpometacarpal Joint Fracture Dislocation of Second to Fifth Finger. Clin Orthop Surg 2015;7(4):430-5. Crossref

31. Asmus A, Eisenschenk A, Eichenauer F, Kim S. Diagnostik und Therapie perilunärer Luxationen und Luxationsfrakturen. Handchir Scan 2017;6(1):51-69. Crossref 
32. Murray PM. Dislocations of the wrist: carpal instability complex. J Hand Surg Am 2003;3(2):88-99. Crossref

33. Riexinger $C$, Laier P. Perilunäre Verletzungen. Unfallchirurg 2018;121(5):358-64. Crossref

34. Mayfield JK, Johnson RP, Kilcoyne RK. Carpal dislocations: pathomechanics and progressive perilunar instability. J Hand Surg Am 1980;5(3):226-41. Crossref

35. Herzberg G, Comtet JJ, Linscheid RL, Amadio PC, Cooney WP, Stalder J. Perilunate dislocations and fracture-dislocations: a multicenter Study. J Hand Surg Am 1993;18(5):768-79. Crossref
36. Dumontier C, Meyer zu Reckendorf G, Sautet A, Lenoble E, Saffar P, Allieu Y. Radiocarpal dislocations: classification and proposal for treatment. A review of twenty-seven cases. J Bone Joint Surg Am 2001;83(2):212-8. Crossref

37. Ilyas AM, Mudgal CS. Radiocarpal Fracture-dislocations. J Am Acad Orthop Surg 2008;16(11):647-55. Crossref

38. Herzberg G. Perilunate and axial carpal dislocations and fracture-dislocations. J Hand Surg Am 2008;33(9):1659-68. Crossref

39. Horton TC, Shin AY, Cooney WP. Isolated scaphoid dislocation associated with axial carpal dissociation: an unusual injury report. J Hand Surg 2004;29(6):1102-8. Crossref 